\title{
PENGARUH KONSENTRASI KENTOS KELAPA TERHADAP DEGRADASI LEMAK DAGING AYAM
}

\section{(The Effect of Coconut Embrio (Kentos) Concentration on Chicken Fat Degradation)}

\author{
Laras Budyghifari $^{\left.1^{*}\right)}$, Sitti Syuhada Dwi Arista ${ }^{1)}$, Andi Nur Fajri Suloi ${ }^{1)}$ dan Amran \\ Laga $^{1)}$ \\ ${ }^{1 *}$ Universitas Hasanuddin, Jl. Perintis Kemerdekaan KM 10 Makassar 90245, Indonesia. \\ ") email Penulis Korespondensi: larasbudyghifari19@gmail.com
}

\begin{abstract}
ABSTRAK
Penyakit kardiovaskular seperti hipertensi, jantung koroner, gagal jantung, dan stroke menyebabkan 17,9 juta orang meninggal dunia atau 31\% dari seluruh kematian global (World Health Organization, 2017). Penyakit ini pada umumnya diakibatkan oleh tingginya konsumsi pangan sumber lemak. Daging ayam bagian paha merupakan salah satu bahan pangan berlemak tinggi (7\%) dibandingkan dengan potongan daging sapi $(6,8 \%)$ dan daging domba (4,9-5,2\%) dengan tingkat konsumsi yang tinggi (Dinh et al., 2011). Ekstrak kasar enzim lipase secara efisien dapat menghidrolisis lemak menjadi asam lemak bebas dan gliserol. Penelitian ini dilakukan untuk melihat pengaruh konsentrasi kentos kelapa sebagai sumber enzim lipase pada hidrolisis lemak daging ayam bagian paha. Kentos kelapa dipreparasi lalu diaplikasikan pada daging ayam dengan konsentrasi 1-5\% dan 10-50\%. Parameter pengamatan meliputi perubahan $\mathrm{pH}$, Total Padatan Terlarut, dan Asam Lemak Bebas. Hasil terbaik untuk tiap parameter ialah perlakukan dengan konsentrasi kentos sebesar $10 \%$ dengan asam lemak bebas sebesar $2.99 \%$, total padatan terlarut sebesar 4,1\% dan pH sebesar 5.3.
\end{abstract}

Kata Kunci : daging ayam, enzim lipase, kentos kelapa

\section{ABSTRACT}

Cardiovascular diseases such as hypertension, coronary heart disease, heart failure, and stroke cause 17.9 million people die or $31 \%$ of all global deaths (World Health Organization, 2017). This disease is generally caused by high consumption of sources of fat. Thigh chicken meat is one of the highest food that contain fat (7\%) compared to beef cuts (6.8\%) and lamb meat (4.9-5.2\%) with high consumption levels (Dinh et al., 2011). The crude lipase enzyme extract can efficiently hydrolyze fat into free fatty acids and glycerol. This study was conducted to look the effect of the concentration of coconut kentos as a source of lipase enzymes on fat hydrolysis of thigh chicken meat. Coconut kentos is prepared and then applied to chicken meat with a concentration of 1-5\% and 10-50\%. Parameters of observation include changes in $\mathrm{pH}$, total dissolved solids, and free fatty acids. The best results for each parameter were concentration $10 \%$ with free fatty acids $2.99 \%$, total dissolved solids $4.1 \%$, and $\mathrm{pH}$ of 5.3 .

Keywords : chicken meat, lipase enzyme, coconut kentos

\section{PENDAHULUAN}

Daging ayam banyak dikonsumsi oleh masyarakat sebagai sumber protein hewani. Menurut Direktorat Gizi Departemen Kesehatan (2010), setiap 100 gram daging ayam mengandung protein sebesar $18,2 \%$, lemak sebesar $25 \%$, serta kalori sebesar 404 Kkal. Rata-rata konsumsi daging ayam broiler selama satu minggu sebanyak 500 gram per orang dengan frekuensi konsumsi satu kali per hari atau per kapita selama seminggu pada tahun 2017 sebesar 0,124 (Winda et al., 2016, Badan Pusat Statistik, 2017). Daging 
ayam bagian paha mengandung lemak sebesar $7,2 \%$, lebih tinggi dari daging sapi sebesar $6,8 \%$, dan bagian otot domba sebesar 5,9-5,2\% (Dinh et al., 2011).

Makanan kaya lemak dengan sendirinya akan mempengaruhi kadar kolesterol darah yang merupakan faktor risiko penyakit kardiovaskular (Pusat Data dan Informasi Kementerian Kesehatan RI, 2012). Penyakit kardiovaskular seperti hipertensi, jantung koroner, gagal jantung, dan stroke menyebabkan 17,9 juta orang meninggal dunia atau $31 \%$ dari seluruh kematian global (World Health Organization, 2017). Salah satu alternatif pencegahan penyakit kardiovaskuler adalah diet rendah lemak.

Lemak dari daging ayam dapat diturunkan menggunakan enzim lipase. Enzim lipase menghidrolisis minyak (trigliserida), digliserida dan mono gliserida menjadi asam lemak bebas dan gliserol (Sana et al., 2004). Ekstrak kasar enzim lipase secara efisien dapat menghidrolisis lemak daging ayam pada kondisi asam (Almeida et al., 2016). Enzim lipase dari kentos kelapa memiliki aktifitas sebesar sebesar 0,0581 unit/mg, limbah kulit semangka dan jeruk memberikan aktivitas lipase sebesar 1,36 U/mL, dedak padi sebesar 0,040 U, dan biji kenari sebesar 0,03- 0,04 $\mu \mathrm{mol} / \mathrm{mg}$ (Su'i et al., 2010, Sumarlin et al., 2013, Firdaus et al., 2017, dan Djarkasi et al., 2017).

Kelebihan enzim lipase yang berasal dari kentos kelapa adalah secara alami telah aktif pada suhu ruang dan telah terimobilisasi secara alami. Enzim yang terimobilisasi menghasilkan stabilitas enzim dan mencegah kontaminasi antara produk dan enzim (Abdullah et al., 2013 dalam Pourzolfaghar et al., 2016). Perlu diketahui konsentrasi enzim yang optimal untuk menghidrolisis lemak daging ayam menjadi asam lemak bebas dan gliserol. Asam lemak bebas adalah asam yang dibebaskan pada hidrolisa dari minyak atau lemak (Maulinda, 2016). Oleh karena itu, penelitian ini dilakukan untuk melihat pengaruh konsentrasi kentos kelapa sebagai sumber enzim lipase pada hidrolisis lemak daging ayam bagian paha.

\section{METODOLOGI PENELITIAN}

\subsection{Alat}

Alat-alat yang digunakan dalam penelitian ini adalah timbangan analitik, mortar dan pastle, pinset, gunting, talenan, tusuk sate, pisau, sendok tanduk, spatula, termometer, pipet volume, bulb, dan erlenmeyer.

\subsection{Bahan}

Bahan-bahan yang digunakan dalam penelitian ini adalah daging ayam bagian paha, larutan buffer, kentos kelapa, alumunium foil, label, kapas, dan karet gelang.

\subsection{Prosedur Penelitian}

Penelitian ini dimulai dengan preparasi daging ayam, preparasi kentos kelapa, dan reaksi enzimatis hidrolisis lemak menjadi asam lemak bebas. Variabel perlakuannya adalah konsentrasi kentos kelapa sebesar 1\%, 2\%, 3\%, 4\%, 5\%, 10\%, $20 \%, 30 \%, 40 \%$, dan 50\%. Parameter pengamatan meliputi perubahan $\mathrm{pH}$, peningkatan total padatan terlarut, dan pembentukan asam lemak bebas.

\subsubsection{Preparasi Daging Ayam}

Daging ayam bagian paha dicuci kemudian difillet lalu dipotong dadu. Daging ayam yang telah dipotong dadu kemudian dimemarkan menggunakan mortar dan pastle lalu ditusuk-tusuk menggunakan tusuk sate. Sampel kemudian ditimbang sebanyak 10 gram untuk masingmasing perlakuan.

\subsubsection{Preparasi Kentos Kelapa}

Kentos kelapa dengan ukuran maksimal diukur diameternya, ketebalan daging, dan tinggi tunasnya. Kentos kelapa lalu dicacah dan ditimbang sesuai perlakuan.

\subsubsection{Reaksi Enzimatis Hidrolisis Lemak Daging Ayam}


Daging ayam yang telah ditimbang sebanyak 10 gram dimasukkan ke dalam suspensi enzim lalu diinkubasi dalam water bath shaker dengan kecepatan pengadukan $200 \mathrm{rpm}$ pada suhu $30^{\circ} \mathrm{C}$ selama 3 jam.

\section{HASIL DAN PEMBAHASAN}

\subsection{Profil Kentos Kelapa}

Tinggi tunas kelapa berkolerasi positif dengan ketebalan daging buah dan diameter kentos. Profil hubungan antara tinggi tunas, ketebalan daging kelapa dan diameter kentos kelapa dapat dilihat pada tabel berikut:

Tabel 01. Profil Kentos Kelapa

\begin{tabular}{lll}
\hline No & \multicolumn{1}{c}{ Parameter } & \multicolumn{1}{c}{ Nilai } \\
\hline 1. & Tinggi Tunas & $25 \mathrm{~cm}$ \\
2. & $\begin{array}{l}\text { Ketebalan daging } \\
\text { kelapa }\end{array}$ & $0.5 \mathrm{~cm}$ \\
3. & Diameter kentos & $13 \mathrm{~cm}$ \\
\hline
\end{tabular}

Hasil pengukuran pada sampel menunjukkan tinggi tunas sebesar $25 \mathrm{~cm}$, ketebalan daging kelapa sebesar $0,5 \mathrm{~cm}$ dan diameter kentos sebesar $13 \mathrm{~cm}$. Tunas kelapa merupakan perpanjangan lembaga buah yang membentuk 4-6 helai daun saling membalut berbentuk selubung runcing yang menembus tempurung kelapa membentuk batang dan daun (Mardiatmoko dan Mira, 2011). Daging buah kelapa berwarna putih dengan ketebalan normal 8 - $10 \mathrm{~mm}$ dan tersusun atas air (52\%), minyak $(34 \%)$, protein $(3 \%)$, zat gula $(1,5 \%)$ dan abu (1\%) (Mardiatmoko dan Mira, 2011). Kentos kelapa merupakan cairan endospermium yang memadat dan mengendap pada dinding buah kelapa ketika buah siap berkecambah (Setyamidjaja, 1985 dalam Hariokusumo, 2016). Enam minggu setelah disemaikan, kentos telah memenuhi permukaan daging buah dan 10 bulan setelah mulai berkecambah daging buah telah habis, selanjutnya kentos menjadi busuk dan tugasnya digantikan oleh akar (Mardiatmoko dan Mira, 2011). Simpson dan Ogorzaly (2001) dalam Su'i (2010) menyatakan pada kelapa tua pangkal embrio tumbuh menjadi organ pengabsorpsi nutrisi yaitu kentos (haustorium) yang perlahan-lahan mengisi seluruh rongga dalam kelapa dan dengan bantuan enzim hidrolitik mengubah cadangan nutrisi untuk pertumbuhan. Menurut Bewley dan Black (1985) dalam Su'i (2010), cadangan makanan dalam daging buah yang berupa lemak dihidrolisa oleh enzim lipase menjadi asam lemak. Asam lemak yang terbentuk kemudian masuk dalam siklus katabolisme, sehingga dihasilkan heksosa yang diperlukan untuk penyusun selulosa. Acquaah (2005) menambahkan bahwa, terjadi metabolisme cadangan makanan selama pertunaasan untuk membentuk sel baru atau jaringan baru.

\subsection{Asam Lemak Bebas}

Asam lemak bebas merupakan substrat yang diperoleh sebagai perombakan trigliserida dari daging ayam oleh enzim lipase dari kentos kelapa. Hasil pengujian asam lemak bebas dapat dilihat pada grafik berikut:

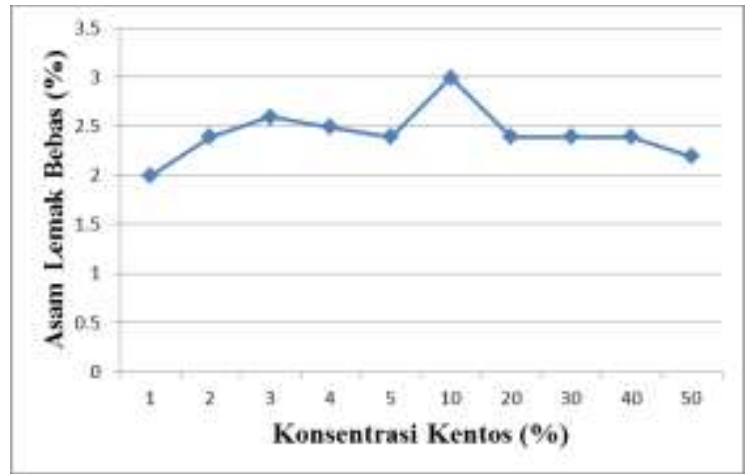

Gambar 01. Hubungan Pembentukan Asam

Lemak Bebas Terhadap Hasil Degradasi

Lemak Daging Ayam

Hasil pengujian asam lemak bebas dari perlakuan perbedaan konsentrasi kentos kelapa sebagai sumber ekstrak kasar enzim lipase menunjukkan hasil tertinggi dari perlakuan konsentrasi enzim 10\% dengan asam lemak bebas sebesar $2.99 \%$ dan hasil terrendah pada perlakuan konsentrasi enzim 4\% dengan asam lemak bebas sebesar $1.59 \%$. Hal ini sesuai dengan penelitian Su'i et al. (2010) bahwa peningkatan 
konsentrasi substrat sampai $10 \%$ dapat meningkatkan produksi asam lemak bebas (FFA) dan terjadi penurunan produksi ketika konsentrasi ditingkatkan. Metabolisme lemak dimulai dengan proses hidrolisis lemak (trigliserida) dari makanan oleh enzim lipase menghasilkan asam lemak bebas dan gliserol (Fajar, 2012).

\subsection{Total Padatan Terlarut}

Padatan terlarut merupakan komponen sederhana yang berasal dari produk hasil hidrolisis. Total padatan terlarut dapat bertambah akibat hidrolisis lemak menjadi asam lemak bebas. Gambar 02 menunjukkan perubahan total padatan terlarut berdasarkan perbedaan konsentrasi kentos sebagai sumber enzim.

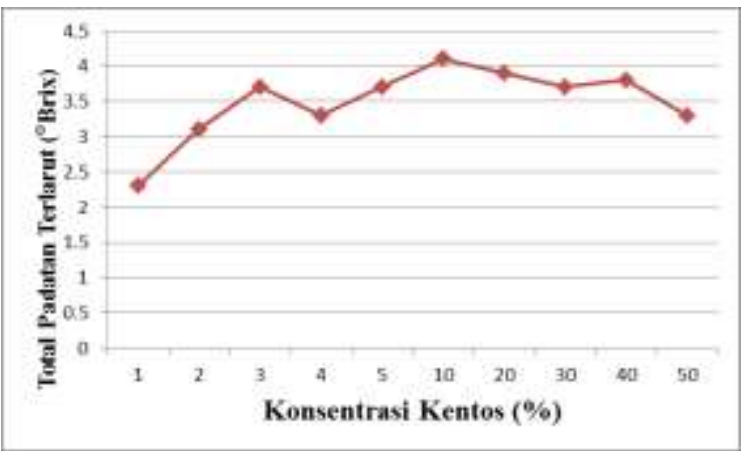

Gambar 02. Hubungan Pembentukan Total Padatan Terlarut Terhadap Hasil Degradasi Lemak Daging Ayam

Hasil pengujian total padatan terlarut dari perlakuan perbedaan konsentrasi kentos kelapa sebagai sumber ekstrak kasar enzim lipase menunjukkan hasil tertinggi dari perlakuan dengan konsentrasi enzim $10 \%$ dengan total padatan terlarut sebesar 4.1\% dan hasil terrendah pada perlakuan konsentrasi enzim 1\% sebesar $2.3 \%$. Hidrolisis lemak yang mengandung asam lemak beratom $\mathrm{C}$ pendek membentuk asam lemak bebas dan gliserol (Nurminabari et al., 2018). Hidrolisis berlanjut menyebabkan enzim bekerja pada substrat yang sudah terlarut dan jumlah asam amino dengan gugus hidrofobik semakin banyak sehingga menurunkan daya kelarutan (Nafi et al., 2014).

\section{$3.4 \mathrm{pH}$}

$\mathrm{pH}$ adalah derajat keasaman yang digunakan untuk menyatakan tingkat keasaman atau kebasaan yang dimiliki oleh suatu larutan (Zulius, 2017). Gambar 03 menunjukkan perubahan $\mathrm{pH}$ berdasarkan perbedaan konsentrasi kentos sebagai sumber enzim.

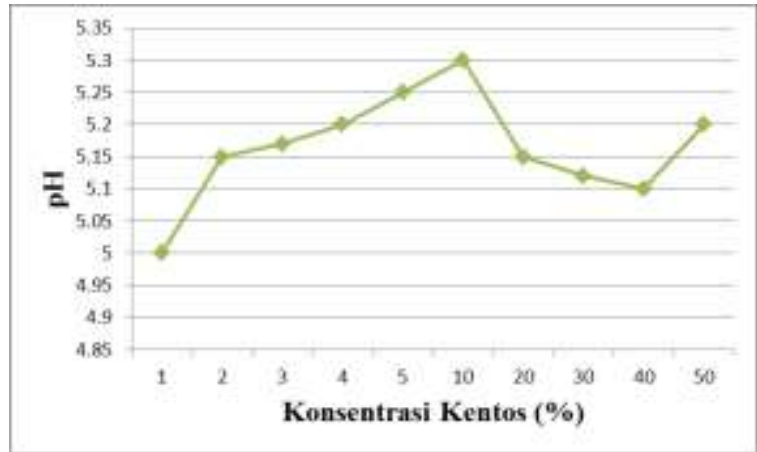

Gambar 03. Hubungan Perubahan $\mathrm{pH}$ Terhadap Hasil Degradasi Lemak Daging Ayam

Hasil pengujian $\mathrm{pH}$ dari perlakuan perbedaan konsensentrasi kentos kelapa sebagai sumber ekstrak kasar enzim lipase menunjukkan hasil tertinggi dari perlakuan konsentrasi enzim $10 \%$ dengan nilai $\mathrm{pH}$ sebesar 5.3 dan nilai $\mathrm{pH}$ terrendah pada konsentrasi enzim $40 \%$ dengan nilai $\mathrm{pH}$ sebesar 5.1. Hasil uji regresi menunjukkan perbedaan perlakuan tidak berpengaruh nyata dengan signifikansi sebesar 0.969 . Ramli (2001) dan Suradi (2008) menyatakan setelah penyembelihan $\mathrm{pH}$ daging ayam turun dari 6.1 menjadi 5.985.82 setelah penyimpanan 10 hingga 12 jam tanpa perlakuan. hasil penelitian Prayitno dan Suryanto (2012) dimana $\mathrm{pH}$ daging ayam broiler tanpa perlakuan apapun adalah 6.11-6.25

\section{KESIMPULAN}

Kesimpulan dari penelitian ini adalah konsentrasi kentos kelapa sebagai sumber enzim tidak berpengaruh nyata terhadap asam lemak bebas, total padatan terlarut, dan $\mathrm{pH}$ hasil reaksi hidrolisis asam lemak bebas pada daging ayam. Hasil terbaik untuk tiap parameter ialah perlakukan K6 
(Konsentrasi 10\%) dengan asam lemak bebas sebesar $2.99 \%$, total padatan terlarut sebesar 4,1\% dan pH sebesar 5.3.

\section{DAFTAR PUSTAKA}

Almeida Af, Dias Kb, Silva Acc, Terrasan Crf, Tornisiello Smt, Carmona Ec (2016). Agroindustrial Wastes As Alternative For Lipase Production By Candida Viswanathii Under SolidState Cultivation: Purification, Biochemical Properties, And Its Potential For Poultry Fat Hydrolysis Enzyme Research. pp. 1-15.

Acquaah, G. (2005), Horticulture: Principles And Practices, 3rd Edition, Pearson Education Inc., London.

Bewley, J.D. And Black, M., (1985). Seeds Physiology of Development And Germination, Plenum Press, New York.

Badan Pusat Statistik (2016) Rata-Rata Produk Peternakan Per Kapita Tahun 2015-216.

Badan Pusat Statistik (2017) Rata-Rata Konsumsi Per Kapita Seminggu Beberapa Macam Bahan Makanan Penting, 2007-2017. Available At: Https:Www.Bps.Go.Id/ (Accessed: 5 April 2019).

Direktorat Gizi Departemen Kesehatan (2010) Daftar Komposisi Bahan Makanan. Jakarta: Penerbit Bhratara.

Djarkasi Sss, Sri R, Zuheid N., (2017) Isolasi Dan Akitivitas Spesifik Enzim Lipase Indigenous Biji Kenari. Jurnal Teknologi Pertanian 8 (1)

Fajar Ag (2012) Pengaruh Subtitusi Tepung Temulawak (Curcuma Xanthorhiza L.) Dan Tepung Kunyit (Curcuma Domestica) Dalam Ransum Terhadap Kandungan Lemak Abdominal Ayam Broiler Strain Cp-707. S1 Thesis, Universitas Negeri Yogyakarta.

Firdaus, Seniwati D, Hendra Jr., (2017). Imobilisasi Enzim Lipase Dedak Padi (Oryza Sativa L.) Pada Karbon Aktif: Karakterisasi, Dan Uji Stabilitas Kerja
Enzim Imobil Indo. J. Chem. Res., 2017, 5(1), 32-36

Hariokusumo, Bimo. (2016) Pengaruh Pemupukan Terhadap Perkembangan Dan Produksi Buah Kelapa Kopyor (Cocos Nucifera L.). Bogor: Institut Pertanian Bogor

Hatma R D., (2012) Sosial Determinan Dan Faktor Risiko Kardiovaskular Jakarta: Kementerian Kesehatan Ri

Kementerian Kesehatan. (2013). Riset Kesehatan Dasar 2013. Diunduh Dari Situs Http://Www.Depkes.Go.Id/ Pada Tanggal 23 Oktober 2018.

Marangoni, F. Et Al. (2015) 'Role Of Poultry Meat In A Balanced Diet Aimed At Maintaining Health And Wellbeing: An Italian Consensus Document', Food And Nutrition Research, 1, Pp. 1-11.

Mardiatmoko, Gun \& Mira Ariyanti. (2011) Produksi Tanaman Kelapa (Cocos Nucifera, L). Ambon: Badan Penerbit Fakultas Pertanian Universitas Pattimura

Nafi., A Nurud D., Rika P., (2014). Pembuatan Garam Gurih Jamur Merang Dengan Variasi Lama Hidrolisis Dan Lama Fermentasi Jurnal Ilmiah Inovasi 14 (2): 125-132

Nurminabari Is Sumartini Dendi Ppa. 2018. Kajian Penambahan Skim Dan Santan Terhadap Karakteristik Yoghurt Dari Whey. Pasundan Food Technology Journal, 5 (1). pp 54-62

Pourzolfaghar H, Faisal A, Wan MAWD, Mohamed KA., (2016). A review of the enzymatic hydroesterification process for biodiesel production Renewable and Sustainable Energy Reviews 61 245-257

Pusat Data dan Informasi Kementerian Kesehatan RI (2012) Gambaran Penyakit Tidak Menular di Rumah Sakit di Indonesia Tahun 2009 dan 2010 (Jakarta: Kementerian Kesehatan $\mathrm{RI})$

Sana, N. K. et al. (2004) 'Identification, purification and Characterization of Lipase from Germinating Oil seeds 
(Brassica napus L.)', Pakistan Journal of Biological Sciences, pp. 246-252.

Setyamidjaja D. (1984). Bertanam Kelapa. Kanisius, Yogyakarta

Simpson, B.B. and Ogorzaly, M.C., (2001) Economic Botany: Plants in Our World, 3rd edition, Mc-Graw Hill Companies Inc., New York.

Su'i M. 2010. Perubahan Fisiologis Buah Kelapa. Selama Germinasi. Agrika, 4(1)

Su'i, M., Harijono, Yunianta, Aulani'am (2010) 'Hidrolysis Activity of Lipase Enzyme from Coconut Houstorium for Coconut Oil', Agritech, 30(3), pp. 164167.

Sumarlin L O, Mulyadi D, Suryatna, Asmara Y 2013 Identifikasi Potensi Enzim Lipase dan Selulase pada Sampah Kulit Buah Hasil Fermentas Jurnal Ilmu Pertanian Indonesia (JIPI), 18(3) 159166

World Health Organization. 2017. Cardiovaskular Diseases (CVDs). Diunduh dari http://www.who. int/en/ne ws-room/fact -sheets/det ail/ca rdiovascular-diseases-(cvds), diakses pada 22 Oktober 2018. 